Int. J. Electrochem. Sci., 15 (2020) 12587 - 12598

International Journal of

ELECTROCHEMICAL

SCIENCE

WWW.electrochemsci.org

\title{
Electrochemical Determination of Methandrostenolone Using a Molecularly Imprinted Sensor
}

\author{
Linlin Shan \\ College of Physical Education, Zhengzhou University of Science and Technology, Zhengzhou, Henan \\ 450064, China \\ E-mail: linlinshan@sutcm.net
}

doi: $10.20964 / 2020.12 .62$

Received: 1 July 2020 / Accepted: 28 September 2020 / Published: 31 October 2020

\begin{abstract}
Anabolic androgenic steroids have a chemical structure similar to that of testosterone and are the most commonly abused and most frequently used sports stimulants. This work proposes a simple methandrostenolone electrochemical sensor based on a nanocomposite with the assistance of molecular imprinting technology. Three-dimensional Au nanowires (AuNWs) were first synthesized using an ionic liquid (IL) as the guiding agent. The adhesion properties of the IL are used to fix Pt nanoparticles to obtain PtNPs/AuNWs/IL. At the same time, the PtNPs/AuNWs/IL nanocomposite was loaded on the surface of a carboxylated reduced graphene oxide-modified electrode. Then, the methandrostenolone electrochemical sensor was constructed by electropolymerization of o-phenylenediamine with the imprinting of metandienone.
\end{abstract}

Keywords: Electrochemical sensor; Metandienone; Voltammetric determination; Molecular imprinted sensor; Stimulant

\section{FULL TEXT}

(C) 2020 The Authors. Published by ESG (www.electrochemsci.org). This article is an open access article distributed under the terms and conditions of the Creative Commons Attribution license (http://creativecommons.org/licenses/by/4.0/). 